\title{
VALUE CHAIN MAPPING AND ACTORS' VALUE ADDED SHARE IN THE CATFISH VALUE CHAIN IN IMO STATE, NIGERIA
}

\author{
${ }^{1}$ Igwenagu M. O., ${ }^{1}$ Ohajianya D. O., ${ }^{1}$ Nwaiwu I. U. O., ${ }^{2}$ Gbolagun, A. O and ${ }^{1}$ Ehirim, N. C \\ ${ }^{I}$ Department of Agricultural Economics, Federal University of Technology, Owerri, Imo State \\ ${ }^{2}$ Department of Agricultural Science Education, Federal College of Education, Eha-Amufu, Enugu \\ State
}

Corresponding author: anthonygbolagun@hotmail.com

\begin{abstract}
The study assessed the value chain mapping and actors value added share in the catfish value chain in Imo State, Nigeria. Multi-stage sampling technique was employed in the selection of 217 catfish value chain actors comprising 37 input suppliers, 50 producers, 50 processors, 50 marketers and 30 consumers for the study. Data were analyzed using value chain map, net income, value added share models and Analysis of Variance (ANOVA). The results indicated that primary actors are inputs suppliers, producers, processors, marketers and consumers while research, finance and legislation activities were carried out by support actors. The total value added in the catfish value chain system was $\$ 2,944.5 / \mathrm{kg}$ with value added share of $0.41 \%, 15.54 \%, 24.83 \%$ and $59.22 \%$ for input suppliers, producers, processors and marketers respectively and they were statistically significantly difference at 5\% with marketers having the highest value added share as they occupy a pivotal position to harness the preference, place, price and product information from the final consumers who are at the epicentre of the value chain system. It was therefore recommended that actors at every node should ensure their efforts should be done in a manner that will attract better value by considering the final consumers' preference of catfish products.
\end{abstract}

Keywords: Catfish, actors, value chain map and value-added share

https://dx.doi.org/10.4314/jafs.v18i2.9

\section{INTRODUCTION}

Michael Porter was the first to use the term value chain in the 1980 s to describe the various activities which were performed in particular links in the chain (Coulibaly et. al., 2010). Value chain involves the sequential linkages through which inputs such as raw materials and production resources are converted to products into the market for final consumption. It identifies the set of actors (primary and secondary actors) and a set of activities performed at each chain node involved in bringing a raw agricultural product from production in the field to final consumption, where at each stage value is added to the product (Coulibaly et. al., 2010). Value chain is thus a chain of activities products pass through all activities of the chain in sequence and at each activity the product gains some value (Alam, et al., 2012). It therefore describes a high-level model of how businesses receive raw materials as input (land, water, labour and capital), add value to the raw Journal of the Faculty of Agriculture and Veterinary Medicine, Imo State University Owerri website: www ajol.info; Attribution: Non-commercial CC BY-NC 
materials through various processes and sell finished products to customers (Alamet al., 2012). The nature of value chain activities differs greatly in accordance with the types of fish production the farmer is involved in (Ardjosoediro and Neven, 2008). Value chains for pisciculture differ between fish types as well as fish management and frequently within and outside various regions (De Silva, 2011). The goal is to deliver maximum value for the least possible total cost (Coulibaly et. al., 2010).

Nigeria produces around 1.06 million tons of fish per year: over 750,000 tons from capture fisheries and roughly 310,000 tons from aquaculture. However, household fish consumption in Nigeria measured at $13.3 \mathrm{~kg} /$ capita/year is low compared with the world's average of 20.3 $\mathrm{kg} / \mathrm{capita} / \mathrm{year}$. This national average likely masks a much lower average among resource limited and vulnerable population groups as well as a notable supply-demand gap. The notable local production shortfall and obvious need to meet the country's huge domestic demand resulted to national fish imports amounting to about USD 1.2 billion making Nigeria a net importer of fishery products (Bradley et. al., 2020).

In order to address the supply-demand shortfall, Imo state in aligning with Federal Government of Nigeria, created the fisheries component in the Agricultural Development Programme to support fish farmers with many technologies and favourable environment for improved local fish production and other component of its value chain (IMO-ADP, 2018). Regardless of this effort, fish value chains in Nigeria are not yet developed to meet resulting in grossly inadequate supply of fish and fish products into domestic markets (Investopedia, 2014). There is gross inefficiency at every node of catfish value chain in Nigeria which is evidenced in the low average household fish consumption. For instance, inadequate supplies from the local fish farmers has been attributed to the use of poor quality fingerlings, inadequate information, high cost of feeds, traditional techniques, small size of holdings, inefficiency in resource use, poor infrastructural facilities, lack of credit, high cost of industrial feed, lack of extension agents, lack of veterinary doctors and lack of fish production equipment and low capital investment (Adeogunet al., 2007; Inoni, 2007; Ugwumba and Nnabuife, 2008; Adinya and Ikpi, 2008; Ugwumba and Chukwuji, 2010; Adinyaet al., 2011; Madubuike, 2012).

It is noteworthy that increased fish production without commensurate effort to improve efficiencies of processing and marketing would still amount to widening demand - supply gap because agricultural production is never in isolation of these critical components: processing, marketing and distribution. The practices and processes of processing, preservation, and trade are performed in an unorganized manner which affects the performance of the sector (Adebayo, Polycarp and Anyanwu, 2016). Therefore, any inefficiency experienced in the fish marketing structure could jeopardize efforts towards increased production and reducing existing demandsupply gap. Marketing of fish is not usually a direct simple link between the producer and consumer thus prices of fish change as it passes through middlemen such that by the time it reaches consumers it becomes expensive and not affordable by low-income household. 
Most of the catfish value chain actors encountered marketing and processing challenges as a result of lack of storage facilities, hence they could not sell their fish fresh at appropriate prices, the issue of value addition as marketers have no access to modern smoking kilns which could increase their ability to sell catfish either in fresh or smoked form also posed a significant challenge. According to Obasi (2014), factors such as low pricing of their product as a result of economic status of the consumers, availability of substitutes and competition for sales, access to credit, awareness, unavailability of water, lack of access road and high transportation cost, lack of storage facilities and high labour cost contributed to inefficient market of catfish as a consequent widening the demand-supply gap of fish consumption leading to poor protein intake, malnutrition, food insecurity and hunger among people.

Previous studies on catfish in Imo State dwelt mostly on the economics of catfish production, marketing of processed catfish and demand for fish using time series data and demand system approach (Ohajianya et al., 2006; Nwosu et al., 2007; Fatunla et al., 2002). There is scanty information on the value-added activities and the share profit of the various actors in the catfish vale chain in Imo state. This study therefore analysed actors value added share along catfish value chain in Imo state to fill this gap in literature and proffer empirical recommendation to the challenges in the catfish value chain in the State.

\section{METHODOLOGY}

This study was carried out in Imo state. Imo state is located in the South - Eastern area of Nigeria and shares boundaries with Anambra, Abia, Delta and Rivers states (NPC, 2006). It is located between latitude $5^{0}$ and $6^{0}$ North and longitude $6^{0}$ and $7^{0}$ East with a total land mass of about 5,100 square kilometres and a population of about 3.9million (NPC, 2006). The State has 27 Local Government Areas grouped into three agricultural zones, viz, Orlu, Owerri and Okigwe. The people of the State are mostly rural which makes their occupational distribution tilted towards agricultural production. The climate is of two types: the dry and wet seasons with intervening cold and dry Harmattan period usually experienced during December and January. The State has an annual rainfall ranges from 2000 to $2500 \mathrm{~mm}$, while maximum average temperature ranges between $30^{\circ} \mathrm{C}$ to $35^{\circ} \mathrm{C}$ (Imo ADP, 2009).

A multi-stage sampling technique comprising purposive, proportionate and random sampling procedures were adopted in the selection of respondents for the study. The sampling frame of 448 catfish actors consisting of the list of catfish input suppliers, producers, processors (smoked catfish), marketers and consumers was sought through the catfish actors' associations in the selected areas. The fourth stage involved a proportionate sampling of actors across the selected villages based on the number of the actors collected in the sample frame to have 217 actors comprising 37 input suppliers, 50 catfish producers, 50 catfish processors, 50 catfish marketers and 30 consumers for the study. 
Primary data were collected using, questionnaire alongside personal observation and key informant interviews. Data were analysed using value chain map and value share model. ANOVA was used to test significance differences of the actors' value share. According to Coulibaly et. al (2010), the value addedis the amount of value that each actor in the chain adds. It is the difference between the price the actor sell the value added product and the price he pays for the raw purchased from the preceding actor i.e

$\mathrm{VA}_{\mathrm{i}}=\mathrm{P}_{1}-\mathrm{P}_{-1} \quad$. $\quad . \quad$. $\quad . \quad$.

Where

$\mathrm{VA}_{\mathrm{i}}=$ value added by the each chain actor

$\mathrm{i}=$ input suppliers, producers, processors and marketers

$\mathrm{P}_{1}=$ price actor offered to sell valued product to the subsequent actor

$\mathrm{P}_{-1}=$ price actor purchased product from the preceding actor.

Therefore,

$\mathrm{VA}_{\text {input supplier }}=\mathrm{P}_{\text {fingerling }}-\mathrm{P}_{\text {breedingstock }}$

$\mathrm{VA}_{\text {producer }}=\mathrm{P}_{\text {harvested fish }}-\mathrm{P}_{\text {fingerling }}$

$\mathrm{VA}_{\text {processor }}=\mathrm{P}_{\text {proccesed fish }}-\mathrm{P}_{\text {harvested fish }}$

$\mathrm{VA}_{\text {marketer }}=\mathrm{P}_{\text {marketer fish }}-\mathrm{P}_{\text {processed fish }}$

Hence, value shareis the percentage share of an actor in the total value added in the value chain system. i.e

$\% \mathrm{VA}_{\mathrm{i}}=\frac{\mathrm{VA}_{\mathrm{i}}}{\sum_{\mathrm{i}=1}^{\mathrm{n}} \mathrm{VA}_{\mathrm{i}}}$

All products that passed through the value chain was measured in $\mathrm{kg}$ to allow for easy comparism of the activity of the chain actors.

The Analysis of Variance (ANOVA) was performed using compare the Scheffe test of the Analysis of variance (ANOVA) multiple means comparison. The ANOVA model is specified following Ohajianya and Osuji, (2012).

$$
\begin{array}{ll}
\mathrm{F}=\frac{\mathrm{MSSB}}{\mathrm{MSSW}} & =\frac{\mathrm{SSB} /(\mathrm{k}-1)}{\mathrm{SSW} /(\mathrm{n}-\mathrm{k})} \\
\text { TSS (total sum of square) } & =\mathrm{SSW}+\mathrm{SSB} . \\
\mathrm{n}_{\mathrm{j}} \mathrm{n}
\end{array}
$$

$\mathrm{SSW}\left(\right.$ sum of square within group) $=\sum \sum\left(\overline{\mathrm{X}_{\mathrm{ij}}}-\overline{\mathrm{X}_{\mathrm{j}}}\right)^{2}$

$$
\mathrm{i}=\mathbf{1} \mathbf{j}=\mathbf{1}
$$

Journal of the Faculty of Agriculture and Veterinary Medicine, Imo State University Owerri website: www ajol.info; Attribution: Non-commercial CC BY-NC 
$\mathrm{n}$

$\mathrm{SSB}=\sum\left(\overline{\mathrm{X}} \mathrm{j}-\overline{\mathrm{X}}^{2} \quad \cdot \quad . \quad\right.$.

$\mathrm{i}=\mathbf{1}$

Where,

$\mathrm{X}_{\mathrm{ij}}=\mathrm{i}^{\text {th }}$ value added of the chain actor $\mathrm{j}$,

$\underline{\underline{X j}}=$ Mean value added responding actors $\mathrm{j}$

$\mathrm{X}=$ Grand mean value added of all actors,

$\mathrm{SSB}=$ Sum of squared deviations between the scores

SSW $=$ Sum of squared deviations within the scores ,

$\mathrm{n}_{\mathrm{j}}=$ Sample size of chain actors $\mathrm{j}$

$\mathrm{n}=$ Sample size of chain actors in all categories,

$\mathrm{K}=$ Number of actors categories

k-1 = Degrees of freedom for SSB (numerator),

$\mathrm{n}-\mathrm{k}=$ Degrees of freedom for SSW (denominator)

$\mathrm{F}=$ Value by which the statistical significance of the mean differences was judged

\section{RESULTS AND DISCUSSION}

\section{Catfish Value Chain Mapping and Roles of the Actors}

The Value Chain Map of Catfish in Imo State was illustrated in Figure 1. This shows the map of the overall catfish value chain, the segments, their interdependencies and linkages in the study area.

Input Supplier - The input dealers in the catfish aquaculture value chain were involved in the sale of brood-stock, feeds, and equipment to the catfish aquaculture farmers. They play an advisory role with respect to stocking density and use of appropriate feeds in term of quality and quantity. The major actors and suppliers of inputs (i.e. Brood-stocks, feeds and equipment) in the study area were private individuals who mostly raised their capital personally. They are categorized into wholesalers and retailerssupplying inputs to the farmers at the normal market prices in an open market. Input dealers were not subsidized by the government at all levels. Soprices of input bought by the catfish farmers were not subsidized.

Producers - The catfish farmers are the most important actors in the industry. These are both out-grower farmers and hatchery producers. From the results, the mean age of the farmers was 41.9 years; about $51.06 \%$ of them were male, majority (50\%) of them used artificial ponds/fibre cages to culture catfish, and they are mostly small-scaled farmers (63\%). Most farms have a Journal of the Faculty of Agriculture and Veterinary Medicine, Imo State University Owerri website: www ajol.info; Attribution: Non-commercial CC BY-NC 
production cycle of six to eight months in which period the catfish under good management is expected to weigh approximately 0.8 to 1 kilogram (Emokaro, Ekunwe and Achille, 2010). The produced fish goes through the intermediary channels of marketing involving other actors or farmers themselves.

Processors - They processors who are involvedmajorly inaddingvaluetocatfish by transforming it into various products. The processing segment of the catfish value chain in the study area is fast becoming an industry of its own as it served as a means of employment for many of the unemployed youths and retired individuals. Majority (54\%) of them are female, with average age of 44.6 years. Smoked fish is the major value-added product processed from catfish with $70 \%$ of the processors involved in it because smoked fish is the most preferred type that is mostly consumed and there is high demand for it. Processing of catfish into smoked fish was very common in the study area and was anindustry gradually opening up to more participants due to low take-off capital. Majority of them are small-scale operators (85\%) processing between $10 \mathrm{kgand} 20 \mathrm{kgeveryday.}$

Marketers - Marketers are the actors involved in the distribution of processed catfish to consumers. In the study area, about 53.2\%ofthemarketers were male. They are involved in marketing fillets (10\%), whole smoked fish (55\%), Fresh fish $(35 \%)$ reaching their consumers at different selling points such as roadside (45\%), public and privates offices (25\%), restaurants, hotels, supermarkets (15\%), markets (50\%). Majority of them are into retail operation (75\%) because itis not capital intensive.

Consumers - The study showed that catfish was mostly consumed by the people in the cities $(65 \%)$ in the study area. This may be because most of the big hotels and restaurants were in the cities and semi-urban areas. The common places of purchase are commodity markets $(15 \%)$, retail shops $(25 \%)$, direct contacts $(25 \%)$, offices $(15 \%)$ and roadsides $(20 \%)$. Again, the income of about $85.5 \%$ of the household consumers of catfish interviewed in the study area were within $\mathrm{N} 10,000-\mathrm{N} 100,000$ per month and average household income was $\mathrm{N} 88,500$ with household size of 6 persons. Considering the large household size and low household income, catfishisnot generally affordable by most households because the average price of catfish consumed by the respondents was $\mathrm{N} 1000$ per kilogram $(\mathrm{kg})$. Also, about $18.5 \%$ of the household catfish consumer claimed theynormallyconsumed $1 \mathrm{kgperweek}, 8.6 \%$ claimedtheyusuallyconsume $2 \mathrm{~kg}$ per week.

Support Actors - Collaborations between farmers and support actors can be divided into four major categories i.e. financial, technical advisory support, information and knowledge, and legislation. Government is the sole actor in the aquaculture legislative instrument in Nigeria. Technologies and innovations like fish handling equipment, techniques of feeding fish and smoking fish were attributed to training by the Fisheries and Aquaculture Departments of the State and Federal Ministries of Agriculture and Natural Resources. 


\section{Estimate of the actors' value-added share in catfish value chain}

The section estimates the costs and returns of the actors along the catfish value chain to evaluate and compare net value added by each actor involved along the catfish value chain. The value added of an actor in the chain is achieved as the price differential of the value-added product sold to the subsequent actor and the price the primary product acquired from the preceding actor. In that case, value added of the producers is the price differential of the catfish sold to the processors and fingerlings acquired from the input suppliers and this is captured the form transformation, place and time value added in the course of the respective activities of actors in the chain (Coulibaly et. al., 2010). In addition, value added share implies the percentage share of an actor in the total value added in the value chain system. The result of the value added of the actors (input suppliers, producer, processor and marketer) in catfish value chains is presented in Table 1. For the input suppliers, the value added which is the price difference in the unit price of the brooded fingerlings sold to the producer $(\$ 15.32 / \mathrm{kg}$ ) and cost of the brooded fingerlings by the input supplier ( $\$ 3.28 / \mathrm{kg}$ ) is given as $\$ 12.04 / \mathrm{kg}$ hence with the total quantity of $31,677.41 \mathrm{~kg}$ brooded and sold to the producer this gave a total value added of $\$ 381,348.00$. For the producers, the value added is given as the price difference in the price of the catfish sold to the processors ( $\$ 473.19 / \mathrm{kg}$ ) and price of the fingerlings purchased from the input supplier $(\mathrm{N} 24.51 / \mathrm{kg}$ ) which is given as $\mathrm{N} 448.68 / \mathrm{kg}$ hence with the total quantity of $1,296.81 \mathrm{~kg}$ of catfish sold, this gave a total value added of $\$ 581,852.1$.For the processor, the value added is given as the price difference in the price of the processed catfish sold to the processors $(\mathrm{N} 1,205 / \mathrm{kg})$ and price of the fresh catfish purchased from the producers ( $\$ 473.19 / \mathrm{kg}$ ) which is given as $\$ 731.81 / \mathrm{kg}$ hence with the total quantity of $826.15 \mathrm{~kg}$ of catfish sold, this gave a total value added of $\$ 604,584.83$. For the marketers, the value added is given as the price difference in the price of the marketed catfish sold to the consumers $(\$ 2,950 / \mathrm{kg})$ and price of the fresh catfish purchased from the producers $(\$ 1,205 / \mathrm{kg})$ which is given as $\$ 1,745 / \mathrm{kg}$ hence with the total quantity of $793.05 \mathrm{~kg}$ of catfish sold, this gave a total value added of $\$ 1,383,871.25$.

The total value added in the catfish value chain system was $\$ 2,944.5 / \mathrm{kg}$ with value added share of $0.41 \%, 15.54 \%, 24.83 \%$ and $59.22 \%$ for input suppliers, producers, processors and marketers respectively. The figure 2 above shows the price flow and value-added share of the catfish value chain actors respectively. It was depicted that the unit cost of brooding fingerling by the input suppliers was $\$ 3.28 / \mathrm{kg}$, input suppliers sold at $\$ 15.32 / \mathrm{kg}$ to the producers. The producers sold the matured catfish at $\mathrm{N} 473.19 / \mathrm{kg}$ to the processors, the processors in turn sold the processed catfish to the marketers at $\$ 1,205 / \mathrm{kg}$. The marketers sold the catfish to the final consumers at $\$ 2,950 / \mathrm{kg}$.

Based on the price flow across the catfish nodes in figure 2, it was estimated that value added by the input suppliers, producers, processors and marketers was $\$ 12.04 / \mathrm{kg}, \$ 448.68 / \mathrm{kg}$, $\$ 731.81 / \mathrm{kg}$ and $\$ 1,745 / \mathrm{kg}$ respectively. The total value added in the catfish value chain system was $\$ 2,944.5 / \mathrm{kg}$. This gave the value-added share of $0.41 \%, 15.54 \%, 24.83 \%$ and $59.22 \%$ for input suppliers, producers, processors and marketers respectively. It implies that value added share of 
the actor increases along the catfish value chain from the input suppliers with least value-added share and the marketers with the highest value-added share. Marketers create the place, time and possession utilities, they satisfy (gives utility to) of what, where, when and how consumers buy, obtained information on the buying behaviour and purchase decisions from the final consumers thereby played vital role in value chain structure.

Testing of hypothesis which states that there are no significant differences in value added among the catfish value chain actors in Imo State was performed using the Analysis of Variance (ANOVA) and the result is presented on Table 2 - 3. From the Table 2, the F-calculated (7.94) was greater than F-tabulated (2.65) at 5\% significant level and degree of freedom $(2,174)$. The null hypothesis that there is no significant difference in value added among the catfish value chain actors in Imo State was rejected and the alternative accepted. This result of significant differences was further exposed to multiple comparison post -hoc test (Scheffe test) which ascertains the sources of the differences. Before-hand, a Bartlett's test of equality of error variances of chi ${ }^{2}$ value was $270.5362(p<0.000)$ showed that the assumption of homogeneity of variance was not violated as it was shown in Table 2. The statistical significance of the differences between each pair of group is presented on Table 3 labelled multiple comparisons which gives the result of the post-hoc tests. From the Table 3, the mean difference value (I-J) indicated that there is significant difference amongst the actors in the catfish value chain, the mean difference between marketer and processors was $\$ 779,286.42$ ( $\mathrm{p}<0.024$ ) which implies that the marketers' net value addition is significantly higher than processors at $5 \%$ statistical level.

\section{Bartlet'stest of equality of error variances - chi $^{2}(3)=270.5362 \quad$ Prob. $^{\prime}>$ chi $^{2}=0.000$}

Also, marketers' net value added was significantly higher than input suppliers by $\$ 1,002,523.25$ $(\mathrm{p}<0.000)$, net value added of the marketers was significantly higher than that of producers by $\$ 802,018.54$ ( $\mathrm{p}<0.002$ ), producers' net value added was significantly higher than input suppliers by $\$ 200,504.71 \quad(\mathrm{p}<0.009)$, processors' net value added was significantly higher than by input suppliers' 223,236.83 ( $\mathrm{p}<0.005)$ and also higher not significantly than the net value added of and producers by $22,732.12(\mathrm{p}<1.000)$ the net value added of the processors is significantly higher than that of the producers by $\$ 166,603.43$ ( $\mathrm{p}<0.01$ ). It could be concluded that the net value added of the actors were significantly different across the catfish value chain nodes.

\section{CONCLUSION AND RECOMMENDATION}

In catfish value chain, each actor contributed to the value added to fingerlings as it moves from production to consumption node of the chain. This highlights the important roles played by input suppliers, producers, processors, marketers and the support actors in the chain. However, it is observed that there are significant differences in value added among the catfish value chain actors in Imo State. The value-added share of the actors increases along the catfish value chain from the input suppliers with least value and the marketers with the highest value-added share. More importantly, value added share of the producers, who formed the most important primary actors in the chain, is grossly low but marketers possessed the highest value-added share. This signifies that marketers enjoyed highest value for their value addition activity while producers are received Journal of the Faculty of Agriculture and Veterinary Medicine, Imo State University Owerri website: www ajol.info; Attribution: Non-commercial CC BY-NC 
lower value for their activity in the chain. It was therefore recommended that actors at every node should ensure their efforts should be done in a manner that will attract better value by considering the final consumers' preference of catfish products. 


\section{REFERENCES}

Adeogun, O. A., Ogunbadejo, H. K., Ayinla, O. A., Oresegun, A., Oguntade, O. R., Tanko, A., and Williams, S. B. (2007). Urban Aquaculture: Producer Perceptions and Practices in Lagos State, Nigeria. Middle-East Journal Science and Resources 2(1): 21-27.

Adinya, I. B., and Ikpi, G. U. (2008). Production Efficiency in Catfish (Clarias gariepinus) Burchell, 1822 in Cross River State, Nigeria. Continental Journal of Fisheries and Aquatic Sci. 2:13-22.

Adinya, I. B., Offem, B. O., and Ikpi, G. U. (2011). Application of a Stochastic Frontier Production Function for Measurement and Comparison of Technical Efficiency of Mandarin Fish and Clown Fish Production in Lowlands Reservoirs, Ponds and Dams of Cross River State, Nigeria. The Journal of Animal and Plant Science, 21(3): 595-600.

Alam, S. P., Idris, A. M., and Madan, M. D. (2012). Marketing of Major Fish Species in Bangladesh: A Value Chain Analysis. Bangladesh.

Ardjosoediro, O. and Neven, D. (2008). The Kenya Capture Fishery Value Chain: An AMAPFSKG Value Chain Finance Case Study. USAID Microreport \#122. Washington DC.

Bradley, B., Byrd, K.A., Atkins, M., Isa, S., Akintola, S.L., Fakoya, K.A., Ene-Obong, H. and Thilsted, S.H. (2020) Fish in food systems in Nigeria: A Review WorldFish. Program Report: 2020-06 retrieved from https://fish.cgiar.org/publications/fish-food-systemsnigeria-review- 0

Coulibaly, O., Arinloye, D., Melle, C., Fanou, J., Agbahey, J., Allomasso, R., Nouhoheflin, T., Koumassa, L., Adetonah S., and Hell, K. (2010). Value Chain Analysis: Analytical toolkit and approaches to guide the development of sustainable African Agrifood ChainsIITAIFAD PRONAF (Cowpea Project for Africa) An IFAD Grant Training Course.

De Silva, D. A. M. (2011). Value chain of Fish and Fishery Products: Origin, Functions and Application in Developed and Developing Country Markets, Value Chain Project, Food and Agriculture Organization. Journal of the Regional Fisheries Society, Japan.

Emokaro, C.O., Ekunwe P.A. and Achille, A. (2010) Profitability and Viability of Catfish Farming in Kogi State, Nigeria. Research Journal of Agriculture and Biological Sciences, 6(3): 215219.

Fatunla, G. T., Oludimu, O. L. and Ladipo, O. O. (2002). A Quantitative Analysis of demand for fish in Nigeria. In: Proceedings of the $2^{\text {nd }}$ Annual Conference of the Fisheries Society of Nigeria. Pp. 201-206.

Hempel, E. (2010), Value Chain Analysis in the Fisheries Sector in Africa. An African Union (AU) I The New Partnership for Africa's Development (NEPAD) initiative. Hempel Consult, Norway.

Journal of the Faculty of Agriculture and Veterinary Medicine, Imo State University Owerri website: www ajol.info; Attribution: Non-commercial CC BY-NC 
Inoni, O. E. (2007). Allocative Efficiency in Pond Fish Production in Delta State, Nigeria: A Production Function Approach. Agric. Tropica et Subtropica, 40 (4): 127-134.

Madubuike, F. N. (2012). Bridging the Animal Protein Supply and Demand Gap in Nigeria. Imo State University, Owerri, Nigeria Inaugural Lecture Series No. 7. Imo State University Owerri.

National Population Commission, NPC (2006). Nigerian population, state by state analysis., Nigeria.

Nwosu, F. O., Oguoma, N. N. O., Ohajianya, D. O. and Ibekwe, U. C. (2007). Factors Influencing Output of fish in Imo State, Nigeria. International Journal and Agricultural and Rural Development (10) 37-40.

Obasi, I. O. (2014). Value Addition, Marketers Welfare and Consumers Preference for Cassava Derivatives in South East Nigeria. A Ph.D Research Thesis Presented to the Department of Agricultural Economics, Michael Okpara University of Agriculture Umudike.

Odukwe, A. (2007). Fish Farming in the Tropics: A Functional Approach. Maxiprints, Awka, Nigeria. Book Review.

Ohajianya, D. O., Onyeagocha, S. U. and Ibekwe, U. C. (2006). Assessment of the Fish Demand Pattern of Households in Imo State, Nigeria. Nigeria Journal of Animal Production, 2 (1): 23-27. https://doi.org/10.4314/apra.v2i1.36307

Ugwumba, C.O. A, and Chukwuji, C. O. (2010). The Economics of Catfish Production in Anambra state, Nigeria: A Profit Function Approach. Journal of Agriculture and Social Science 6 (4): 105- 109.

Ugwumba, C.O.A. and Nnabuife, E.L.C. (2008). Comparative Study on the Utilization of Commercial Feed and Home-made Feed in Catfish Production for Sustainable Aquaculture. Multidisciplinary Journal of Research and Development, 10 (6): 164-169. 


\section{APPENDIX}

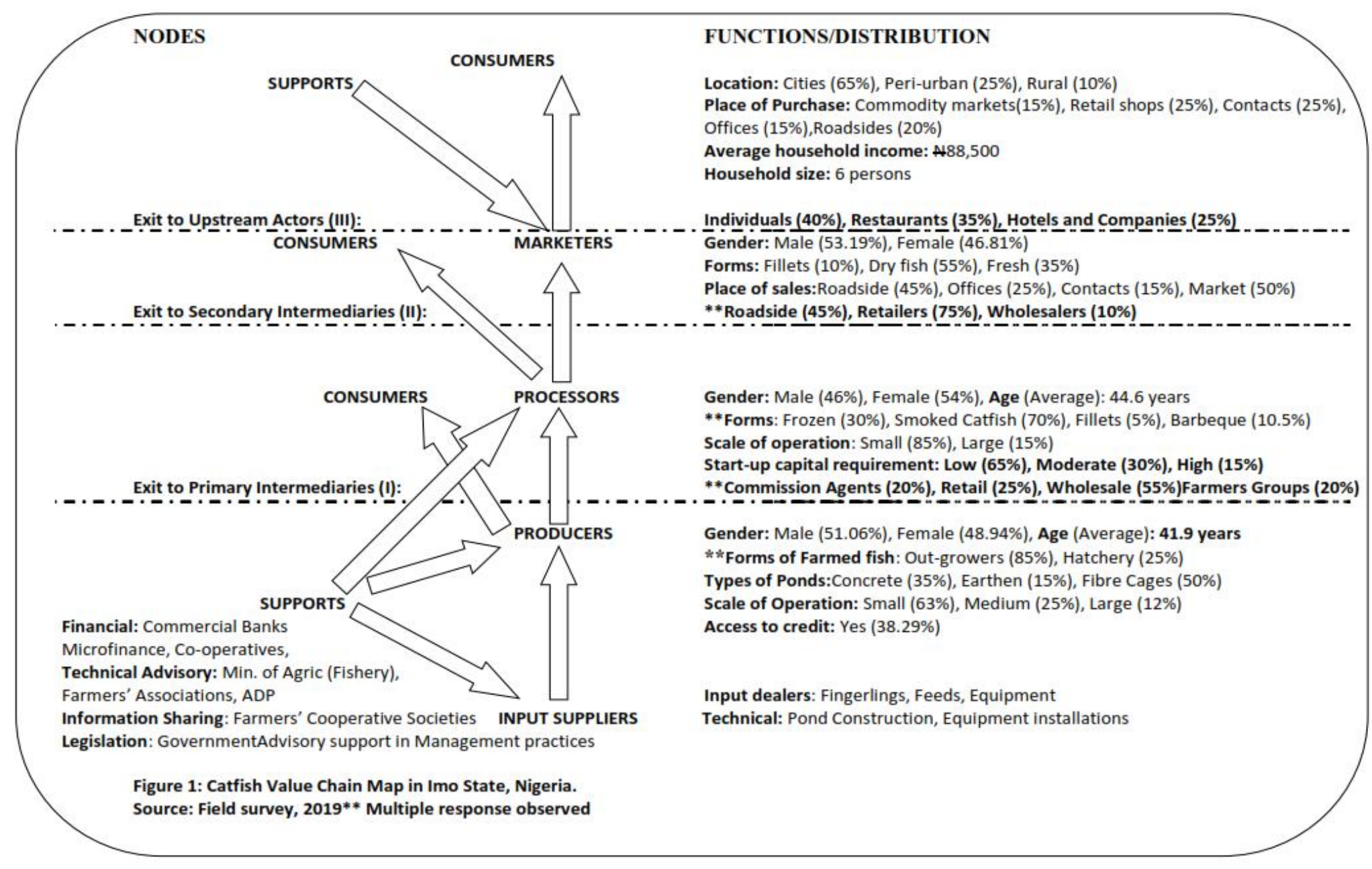

Journal of the Faculty of Agriculture and Veterinary Medicine, Imo State University Owerri website: www ajol.info; Attribution: Non-commercial CC BY-NC 
Journal of Agriculture and Food Sciences

Volume 18, Number 2, October 2020, pp 120 - 13.4

Igwenagu M. O., Ohajianya D. O., Nwaiwu I. U. O., Gbolagun, A. O and Ehirim, N. C

Table 1: Estimate of the actors' value-added share in catfish value chain

\begin{tabular}{|c|c|c|c|c|c|}
\hline \multicolumn{3}{|c|}{ Input Suppliers } & \multicolumn{3}{|c|}{ Processors } \\
\hline Items & Qty & Value (N) & Items & Qty & Value $(\mathrm{N})$ \\
\hline Fingerling brooded $*\left(\mathrm{P}_{\mathrm{fp}}\right)$ & $32,012.20(3.28)$ & $105,000.00$ & Harvested Fish $\left(\mathrm{P}_{\mathrm{hf}}\right)$ & $1,271(473.19)$ & $601,424.49$ \\
\hline Fingerling sold $*\left(\mathrm{P}_{\mathrm{fs}}\right)$ & $31,677.42(15.32)$ & $485,298.00$ & Qty Marketed $\left(\mathrm{P}_{\mathrm{pf}}\right)$ & $826.15(1,205)$ & $995,510.75$ \\
\hline Value added $\left(V_{\text {ai }}\right)=P_{f s}-P_{f p}$ & & 12.04 & Value Added $\left(V_{\text {apr }}\right)=P_{h f}-P_{\text {pf }}$ & & 731.81 \\
\hline Total value added & $31,677.42(12.04)$ & $381,396.14$ & Total value added & 826.15(731.8) & $604,584.83$ \\
\hline \multicolumn{2}{|c|}{ Value added share $\left(V_{s}\right)=V_{a} / C V A$} & $0.65 \%$ & \multicolumn{2}{|c|}{ Value added share $\left(V_{\text {spr }}\right)=V_{a} / C V A$} & $24.85 \%$ \\
\hline \multicolumn{3}{|c|}{$\begin{array}{ll}\text { Producers } \\
\end{array}$} & \multicolumn{3}{|c|}{$\begin{array}{ll}\text { Marketers } \\
\end{array}$} \\
\hline Items & Qty & Value $(\mathrm{N})$ & Items & Qty & Value $(\mathrm{N})$ \\
\hline Fingerling stocked $*\left(\mathrm{P}_{\mathrm{fs}}\right)$ & $1,435.11(24.51)$ & $35,175.37$ & $* *$ Catfish bought $\left(\mathrm{P}_{\mathrm{fs}}\right)$ & $813.05(1,205)$ & $979,725.25$ \\
\hline Catfish sold $\left(\mathrm{P}_{\mathrm{cs}}\right)$ & $1,296.81(473.19)$ & $613,638.75$ & Catfish sold $\left(\mathrm{P}_{\mathrm{cs}}\right)$ & $793.05(2,950)$ & $2,339,497.50$ \\
\hline Value added $\left(V_{\text {ap }}\right)=P_{c s}-P_{f s}$ & & 448.68 & Value added $\left(\mathbf{V}_{\mathrm{am}}\right)=\mathbf{P}_{\mathrm{fs}}-\mathbf{P}_{\mathrm{cs}}$ & & 1745 \\
\hline Total value added & $1,296.81(448.68)$ & $581,852.71$ & Total value added & 793.05 $(1,745)$ & $1,383,871.25$ \\
\hline \multicolumn{2}{|c|}{ Value added share $\left(V_{\text {sp }}\right)=V_{a} / C V A$} & $15.24 \%$ & \multicolumn{2}{|c|}{ Value added share $\left(V_{\text {sm }}\right)=V_{a} / C V A$} & $59.26 \%$ \\
\hline
\end{tabular}

Source: Field Survey Data, 2019

** catfish bought by the marketer represent the average quantity of wholesale and retail marketers

$C V A=$ Chain Value Added $=\sum\left(\boldsymbol{V}_{a i}+\boldsymbol{V}_{a p}+\boldsymbol{V}_{\text {apr }}+\boldsymbol{V}_{a m}\right)=\$ 2946.72 / \mathrm{kg}$

1 fingerling $=6.25 \mathrm{~g}$

All measurements are done on unit price per $\mathrm{kg}$.

Figures in parentheses are the unit prices of the respective items

Journal of the Faculty of Agriculture and Veterinary Medicine, Imo State University Owerri website: www ajol.info; Attribution: Non-commercial CC BY-NC 
Journal of Agriculture and Food Sciences

Volume 18, Number 2, October 2020, pp 120 - 134

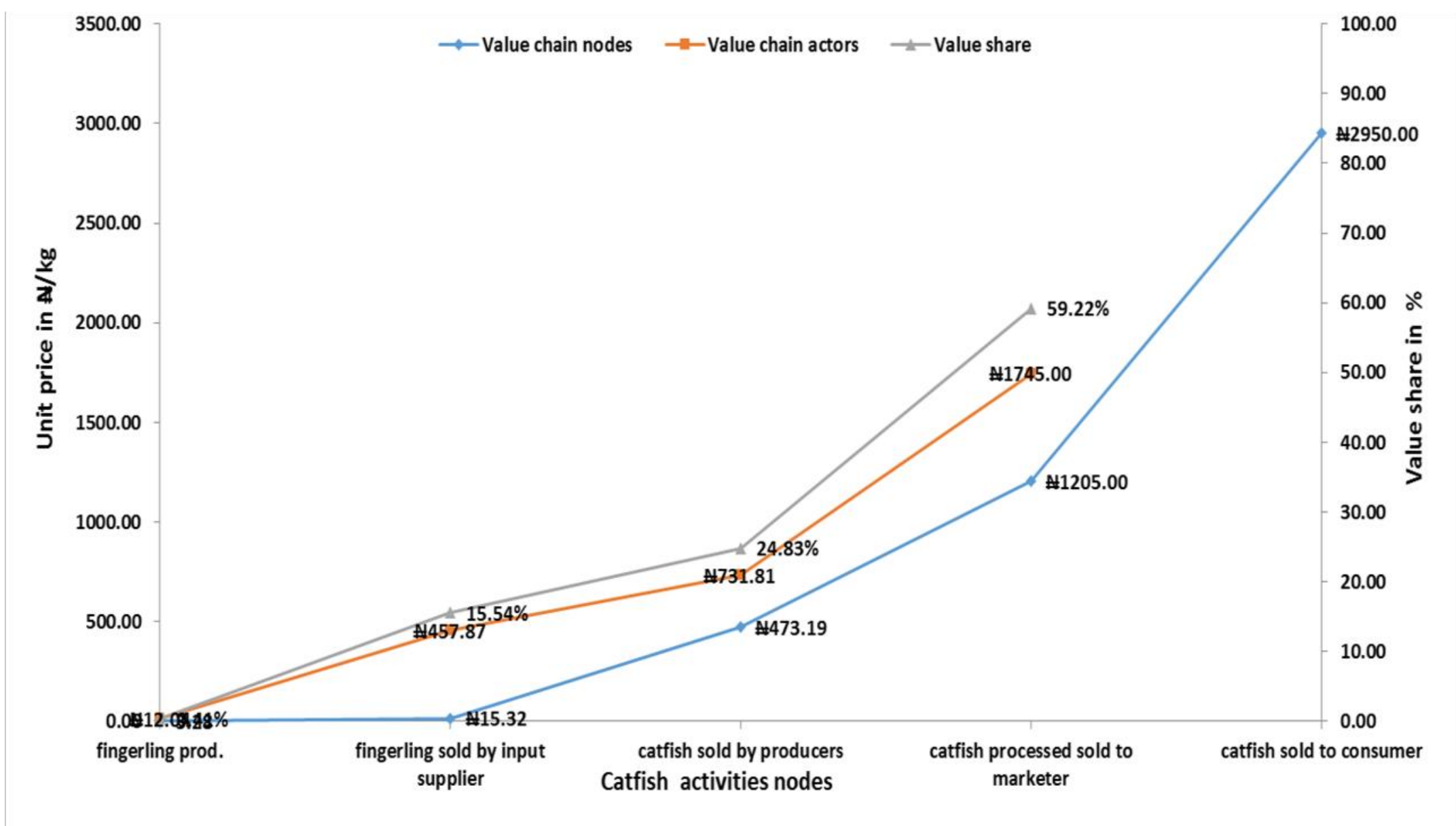

Figure 2: Price flow and value-added share of the catfish value chain actors

Journal of the Faculty of Agriculture and Veterinary Medicine, Imo State University Owerr website: www ajol.info; Attribution: Non-commercial CC BY-NC 
Table 2: Analysis of Variance

\begin{tabular}{lccccc}
\hline Source & $\begin{array}{c}\text { Type III Sum of } \\
\text { Squares }\end{array}$ & df & Mean Square & F & Sig. \\
\hline Between groups & $2.062 \mathrm{e} 13$ & 3 & $.682 \mathrm{e} 12$ & 7.94 & 0.0001 \\
Within groups & $2.0975 \mathrm{e} 14$ & 172 & $1.2195 \mathrm{e} 12$ & & \\
Total & $2.3881 \mathrm{e} 14$ & 15 & $1.3646 \mathrm{e} 12$ & & \\
\hline
\end{tabular}

Source: computed from ANOVA

Bartlett's test of equality of error variances - chi $^{2}(3)=270.5362$.

Prob $.>\operatorname{chi}^{2}=0.000$

Table 3: Multiple comparison of the Post-Hoc

\begin{tabular}{lccc}
\hline Actors & Input suppliers & Producers & Processors \\
\hline Producers & $200,504.71$ & & \\
& $(0.009)^{* *}$ & & \\
Processors & $223,236.83$ & $22,732.12$ & \\
& $(0.005)^{* *}$ & $(1.000)$ & \\
Marketers & $1,002,523.25$ & $802,018.54$ & $779,286.42$ \\
& $(0.000)^{* *}$ & $(0.002)^{* *}$ & $(0.024)^{*}$ \\
\hline
\end{tabular}

Source: computed from ANOVA

Figures in parentheses are the p-values

$*=$ significant at $5 \%$, ** = significant at $1 \%$

Breusch-Pagan /Cook-Weisberg test for heteroskedasticity $-\operatorname{chi}^{2}(I)=7.25$,

Prob $>$ chi $^{2}=0.0071$ 